Vol. 1 No. 02 Hal. 36 - 43

\title{
Aspek - Aspek Pertumbuhan Dan Perkembangan Peserta Didik
}

\author{
Samio, S.Pd, M.Pd \\ Dosen Tetap Yayasan Universitas Alwasliyah Medan \\ samio@ fkip.univa.ac.id
}

\begin{abstract}
ABSTRAK
Manusia sebagai makhluk sosial, senantiasa berhubungan dengan manusia lainnya dalam masyarakat. Sosialisasi pada dasarnya merupakan proses penyesuaian diri terhadap kehidupan sosial. Dengan demikian jelaslah bahwa hubungan sosial merupakan hubungan antar manusia yang saling membutuhkan, baik dari kalangan anak-anak, remaja, dewasa, sampai orang tua. Istilah pertumbuhan tidak bisa dipisahkan secara tajam, namun bila ingin dibedakan maka pertumbuhan lebih mununjuk kepada perubahan fisik sedangkan perkembangan lebih menuju kepada perubahan psikis dimana perubahan-perubahan tersebut terjadi akibat dari kekuatan-kekuatan interen secara otomatis dan kekuatan-kekuatan dari luar.
\end{abstract}

\section{A. Hakikat Pertumbuhan dan Perkembangan Peserta Didik}

Dari berbagai devisi para ahli diperoleh pernyataan bahwa istilah pertumbuhan tidak bisa dipisahkan secara tajam, namun bila ingin dibedakan maka pertumbuhan lebih mununjuk kepada perubahan fisik sedangkan perkembangan lebih menuju kepada perubahan psikis dimana perubahan-perubahan tersebut terjadi akibat dari kekuatan-kekuatan interen secara otomatis dan kekuatan-kekuatan dari luar.

\section{B. PERTUMBUHAN FISIK PESERTA DIDIK}

Pertumbuhan fisik peserta didik adalah Perubahan fisiologis yang bersifat progresif dan kontinu serta berlangsung dalam periode tertentu

\section{Karakteristik}

a. Umum

Berkembangnya organ dan kelenjar, perubahan emosi

b. Wanita

Menstruasi, timbulnya jerawat, lekuk tubuh

c. Pria

Mimpi basah, suara parau, pertumbuhan tinggi yang cepat

\section{Faktor - faktor yang mempengaruhi pertumbuhan fisik :}

a. Pengaruh Keluarga

Pengaruh keluarga meliputi faktor keturunan maupun faktor lingkungan.

1. Faktor keturunan

fisik yang sama dengan salah satu anggota keluarga

2. Faktor lingkungan

pergaulan, kesamaan tingkah laku dengan salah satu anggota keluarga

b. Pengaruh Gizi

Jumlah gizi yang diberikan, berpengaruh pada cepatnya pertumbuhan fisik anak.

c. Gangguan Emosional

Jika anak sering mangalami gangguan emosional, pertumbuhan awal remajanya akan terhambat.

d. Jenis Kelamin 
Berbedanya bentuk tulang dan otot pada anak laki - laki dan perempuan, berpengaruh terhadap perbedaan berat dan tinggi.

e. Status Sosial Ekonomi

Kemampuan ekonomi keluarga dalam mencukupi kebutuhan primer anak, berpengaruh terhadap pertumbuhan fisik anak.

Ex : anak dari keluarga yang status ekonominya rendah, cenderung lebih kecil daripada anak yang berasal dari keluarga yang status ekonominya tinggi

f. Kesehatan

Kurangnya perawatan kesehatan akan menyebabkan anak mudah terserang penyakit, anak yang jarang sakit biasanya akan memiliki tubuh yang lebih berat daripada anak yang sering sakit - sakitan.

g. Pengaruh Bentuk Tubuh

Mesamorf : kekar, berat

Ektomorf : kurus, bertulang panjang

Endomorf : gemuk, berat

Bentuk - bentuk tubuh diatas mempengaruhi besar kecilnya tubuh anak.

\section{Faktor - faktor yang mendorong kelanjutan perkembangan motor skills anak :}

a. $\mathrm{P}$ ertumbuhan dan perkembangan sistem syaraf

Berkaitan dengan tumbuh kembang kecerdasan (meningkatnya kecerdasan dan berubahnya tingkah laku)

b. Pertumbuhan otot - otot

Peningkatan kemampuan dan kekuatan jasmani (dalam menciptakan sesuatu, misalnya kerajinan tangan, akan semakin meningkat kualitasnya dari masa ke masa )

c. Perkembangan dan pertumbuhan fungsi kelenjar endokrin

Mempengaruhi pola sikap dan tingkah laku terhadap lawan jenis ( menarik perhatian lawan jenis, berubahnya gaya / penampilan )

d.Perubahan struktur jasmani

Berpengaruh terhadap perkembangan kemampuan dan kecakapan motor skills anak. Mengubah konsep diri anak tersebut. (Bertambanya ukuran tinggi / berat badan. Perubahan sikap dan perilaku terhadap orang lain.)

\section{PERKEMBANGAN INTELEK PESERTA DIDIK}

Perkembangan Intelektual/kognitif adalah proses yang didalamnya melibatkan proses memperoleh, menyusun, mengunakan pengetahuan, serta keguatan mental seperti berpikir, mengamati, mengingat, menganalisis, mengevaluasi, memecahkan persoalan dengan berinteraksi dengan lingkungan. Intelek adalah kekuatan mental yang menyebabkan manusia dapat berpikir aktivitas yang berkenaan dengan proses berpikir. Intelegensi adalah kemampuan yang diperoleh melalui keturunan dan tidak banyak dipengaruhi oleh lingkungan. Dalam batas-batas tertentu, lingkungan turut berperan dalam pembentukan intelegensi. Hubungan antara intelek dengan tingkah laku. Kemampuan berpikir abstrak menunjukkan perhatian seseorang pada kejadian dan peristiwa yang tidak konkrit, seperti pilihan pekerjaan, corak hidup bermasyarakat, pilihan pasangan hidup yang sebenarnya masih jauh di depannya, dan lain-lain. Bagi remaja, corak perilaku pribadinya di hari depan dan corak tingkah lakunya sekarang akan berbeda. Kemampuan abstraksi akan berperan dalam perkembangan kepribadiannya. Mereka dapat memikirkan prihal itu sendiri. Pemikiran itu terwujud dalam refleksi diri, yang sering mengalah ke penilaian tentang dirinya tidak selalu diketahui orang lain bahkan sering terlihat usaha seseorang untuk menyembunyikan atau merahasiakannya. Pikiran remaja sering dipengaruhi oleh 
ide-ide dan teori-teori yang menyebabkan sikapkritis terhadap situasi dan orang tua. Setiap pendapat orang tua dibandingkan dengan teori yang diikuti atau diharapkan. Sikap kritis ini juga ditunjukkan dalam hal-hal yang sudah umum baginya pada masa sebelumnya, sehingga tata cara, adat istiadat yang berlaku di lingkungan keluarga sering terjadi adanya pertentangan dengan sikap kritis yang tampak pada perilakunya. Selain itu egosentrisme masih terlihat pada pikiran remaja. Cita-cita dan idealism terlalu menitikberatkan pada pikiran sendiri tanpa memperdulikan orang lain. Egosentrisme menyebabkan kekakuan para remaja dalam berpikir dan bertingkah laku. Persoalan yang timbul pada masa remaja adalah banyak berhubungan dengan pertumbuhan fisik yang dirasakan mencekam dirinya, karena menyangka orang lain berpikiran sama dan ikut tidak puas dengan penampilannya. Hal ini menimbulkan perasaan seolah-olah selalu diamati orang lain, perasaan malu dan membatasi gerak-geriknya. Akibat dari hal ini akan terlihat pada tingkah laku yang kaku.. Melalui banyak pengalaman dan penghayatan kenyataan serta dalam menghadapi pendapat orang lain, maka egosentrisme makin berkurang. Pada akhir masa remaja, pengaruh egosentrisme sudah sedemikian kecilnya, sehingga remaja sudah dapat berpikir abstrak dengan mengikutsertakan pendapat dan pandangan orang lain.

\section{Karakteristik}

Intelegensi pada masa remaja tidak mudah diukur, karena tidak mudah terlihat perubahan kecepatan perkembangan kemampuan tersebut. Pada umumnya umur tiga sampai empat tahun pertama menunjukkan perkembangan kemampuan yang hebat, selanjutnya akan terjadi perkembangan yang teratur. Pada masa remaja kemampuan untuk mengatasi masalah yang majemuk bertambah. Pada awal masa remaja, kira-kira pada umur 12 tahun, anak berada pada masa yang disebut masa operasi formal (berpikir abstrak). Pada masa ini remaja telah berpikir dengan mempertimbangkan hal yang "mungkin" di samping hal yang "nyata" (Gleitman, 1986).

Berpikir operasional-formal memiliki dua sifat yang penting, yaitu:

1. Sifat deduktif - hipotesis. Dalam menyelesaikan suatu masalah, seorang remaja akan mengawalinya dengan berpikir teoritik. Ia menganalisis masalah dan mengajukan cara penyelesaian hipotesis. Pada dasarnya pengajuan hipotesis itu menggunakan cara berpikir induktif di samping deduktif. Oleh sebab itu, sifat berpikir ini sebenarnya mencakup deduktif - induktif - hipotesis.

2. Berpikir operasional juga berpikir kombinatoris. Sifat ini merupakan kelengkapan sifat yang pertama dan berhubungan dengan cara bagaimana melakukan analisis. Anak berpikir operasional formal terlebih dahulu secara teoritik membuat matrik mengenai macammacam kombinasi yang mungkin, kemudian secara sistematik mencoba mengisi sel matriks tersebut secara empiric

Faktor-faktor yang mempengaruhi perkembangan intelek

a. Faktor Herederitas

Sejak dalam kandungan, anak telah memiliki sifat-sifat yang menentukan daya kerja intelektualnya. Secara potensial anak telah membawa kemungkinan apakah akan menjadi kemampuan berpikir setaraf normal, dibawah normal, atau diatas normal. Namun pengaruh lingkungan sangat menentukan perkembangan intelektual anak.

b. Faktor Lingkungan

Kecerdasan seseorang anak dapat berkembang jika lingkungan memberikan kesempatan untuk berkembang secara maksimal. Menurut Andi Menpiare (1982:80)dalam hal-hal yang mempengaruhi perkembangan intelek dalam lingkungn antara lain:

1). Bertambahnya informasi yang disimpan (dalam otak) seseorang sehingga ia mampu berfikir reflektif. 
2).Banyaknya pengalaman-pengalaman memecahkan masalah sehingga seseorang dapat berpikir proporsional.

3). Adanya kebebasan berfikir, sehingga anak dapat memecahkan masalah dan menarik kesimpulan. Faktor lingkungan seseorang berbeda-beda sehingga informasi dan pengalaman yang diperolehnya pun berbeda-beda, misalnya:

a). Keluarga

Adalah faktor yang paling penting dimana pihak keluarga khususnya orang tua harus memberikan informasi dan pengalaman sehingga anak dapat memiliki berbagai kemampuan dan cara berpikir yang cepat.

b). Sekolah

Adalah lembaga formal yang bertanggung jawab meningkatkan perkembangan anak. Kita sebagai pendidik harus dapat mengetahui cara untuk meningkatkan perkembangan intelek anak, misalnya :

(1). Menciptakan interaksi yang akrab dengan peserta didik sehingga ia merasa nyaman untuk mengkonsultasikan masalah yang dimilikinya kepada kita

(2). Memberikan kesempatan kepada siswa untuk mencari ilmu atau pengetahuan dari berbagai sumber yang menunjang perkembangan intelektnya.

(3). Meningkatkan pertumbuhan anak, misalnya kegiatan olahraga , member gizi yang cukup, dan sebagainya. Sehingga perkembangan intelektualnya tidak akan terganggu oleh perkembangan fisik.

(4). Meningkatkan kemampuan berbahasa peserta didik agar dia dapat berdialog dan berinteraksi dengan mudah. Setiap individu memiliki kemampuan berpikir yang berbedabeda. Ini merupakan tugas guru agar dapat meningkatkan kemampuan intelek anak. Agar kemampuannya dalam berpikir samarata. Kita juga harus bisa mengoptimalkan kemampuan otak anak dalam peningkatan intelek anak dengan mengetahui susunan otak dan teori belahan otak dan bagaimana mengoptimalkannya.

\section{PERKEMBANGAN BAKAT KHUSUS PESERTA DIDIK REMAJA}

Perbedaan Individu juga bergantung pada tingkat kemampuan / prestasi.

Bakat adalah bawaan sejak lahir.

\section{Pengertian Bakat}

Sifat yang dianggap sebagai kemampuan individu untuk menerima latihan / respon seperti bahasa, musik, dll.

\section{Jenis Bakat Khusus}

a. Setiap individu memiliki bakat khusus yang berbeda.

b. Usaha pengenalan bakat mula-mula terjadi pada bidang pekerjaan, kemudian pada bidang pendidikan.

c. Pemberian nama terhadap jenis-jenis bakat khusus biasanya dilakukan bidang apa bakat tersebut berfungsi (matematika, seni, musik, dll).

d. Bakat khusus bergantug pada kebudayaan tempat seorang individu di besarkan.

e. Faktor linkungan sangat berpengaruh.

\section{Hubungan Bakat dan Prestasi}

a. Dengan adanya bakat, seseorang dapat mencapai prestasi dalam bidang tertentu.

b. Bakat yang tersalurkan + orangtua menyadari dan berupaya agar anak mendapatkan pengalamanyang baik untuk pengembangan bakatnya + minat dari anak yang bersangkutan $=$ prestasi yang unggul

\section{Faktor Yang Mempengaruhi Perkembangan Bakat}

a. Anak itu sendiri : misal, anak kurang berminat, kurang termotivasi, mempunyai, hambatan pribadi

b Lingkungan anak : orang tua kurang mampu menyediakan sarana dan kesempatan 


\section{Pendidikan Anak Berbakat di Indonesia}

a. Kurikulum yang terpusat (secara umum sama di seluruh NKRI) --> mulai dari TK, SD, SLTP, SLTA. Sehingga bersifat terbatas.

b. Pendidika anak berbakat serupa dengan pendidikan pada umumnya, hanya saja jika dilihat dari sistem pengajaran meliputi program, fasilitas, guru, masukan, dan tujuan.

\section{1). Pengertian anak berbakat}

Adalah anak yang mempunyai potensi unggul di atas potensi yang dimiliki oleh anak-anak normal. Sementara itu, kepribadian merupakan sumbangan yang dapat di berikan oleh anak / orang berbakat. Dengan dasaar keribadian yang baik akan lahir karya yang baik pula.

\section{2). Karakteristik anak berbakat}

Ada bnyak faktor yang mempengaruhi karakteristik / watak dari anak berbakat, diantaranya : pertumbuhan dan perkembangan, budaya, agama.

Untuk mengenali karakteristik bisa di lihat dari beberapa segi:

a). Potensi

b). Cara menghadapi masalah

c).Prestasi

\section{3) Menangani anak berbakat}

Membiarkan anak berkembang sendiri akan mengakibatkan perkembangan tidak sempurna dan bakat yang sebetulnya dimiliki menjadi tidak berfungsi. Dalam upayanya ada beberapa faktor yang perlu di perhatikan agar mencapai hasil yang di harapkan.

a). Faktor yang ada pada anak itu sendiri.

b). Faktor kurikulum yang meliputi.

4). Pelaksanaan pendidikan anak berbakat

a).Meloncatkan anak pada kelas yang lebih tinggi

b).Pendidikan dalam kelas khusus

c).Kegiatan dalam implementasi kurikulum bidang studi tetentu

d).Metode belajar dan guru

6. Implikasi Pengembangan Bakat Khusus Remaja terhadap Penyelenggaraan Pendidikan

Dalam suasana yang aman secara psikologis, anak akan merasa nyaman untuk mengungkapkan dan mengekspresikan bakatnya. Pendidikan hendaknya berfungsi sebagai media pangembangan dan pembinaan bakat anak. Pengenalan bakat dan upaya pengembangannya membantu remaja untuk menentukan pilihan yang tepat dan menyaiapkan dirinya untukmacapai tujuan dan karier kehidupannya.

\section{PERKEMBANGAN HUBUNGAN SOSIAL PESERTA DIDIK}

\section{Pengertian Hubungan Sosial}

Teori psikologi telah mengungkapkan bahwa manusia tumbuh dan berkembang dari masa bayi ke masa dewasa melalui beberapa langkah, tahapan, dan jenjang. Kehidupan anak pada dasarnya merupakan kemampuan berhubungan dan berinteraksi dengan lingkungan sosial budayanya. Manusia sebagai makhluk sosial, senantiasa berhubungan dengan manusia lainnya dalam masyarakat. Sosialisasi pada dasarnya merupakan proses penyesuaian diri terhadap kehidupan sosial. Dengan demikian jelaslah bahwa hubungan sosial merupakan hubungan antar manusia yang saling membutuhkan, baik dari kalangan anak-anak, remaja, dewasa, sampai orang tua.

\section{Karakteristik Perkembangan Remaja}


Dalam penyesuaian diri terhadap lingkungan, remaja mulai memerhatikan berbagai nilai dan norma pergaulan, yang berbeda dengan norma yang berlaku di keluarganya. Ia mulai memahami nilai dan norma pergaulan dalam kelompok remaja, kelompok anak-anak, kelompok orang dewasa, dan kelompok orang tua. Pergaulan remaja banyak diwujudkan dalam bentuk kelompok, baik kelompok kecil maupun kelompok besar. Penetapan pilihan kelompok yang diikuti didasari oleh berbagai pertimbangan seperti, moral, ekonomi, minat, kesamaan bakat dan kemampuan. Nilai positif dalam kehidupan kelompok adalah tiap-tiap anggota belajar berorganisasi, memilih pemimpin, dan mematuhi peraturan kelompok. Penyesuaian diri dalam kelompok kecil yang terdiri dari pasangan remaja berbeda jenis tetap menjadi permasalahan yang cukup berat. Dalam hal ini kemampuan intelektual dan emosional mempunyai pengaruh yang kuat.

\section{Faktor - Faktor Yang Mempengaruhi Perkembangan Sosial}

Perkembangan sosial dipengaruhi oleh banyak faktor, antara lain keluarga, status sosial ekonomi keluarga, tingkat pendidikan, dan kemampuan mental, terutama emosi dan intelegensi.

\section{Faktor Keluarga}

Keluarga merupakan lingkungan pertama dan utama yang memberikan banyak pengaruh terhadap berbagai aspek perkembangan sosial anak. Keluarga merupakan media sosialisasi yang paling efektif bagi anak.

\section{Kematangan}

Proses sosialisasi tentu saja memerlukan kematangan fisik dan psikis. Untuk memberi dan menerima pandangan atau pendapat orang lain diperlukan kematangan intelektual dan emosional.

\section{Status Sosial Ekonomi}

Kehidupan sosial dipengaruhi pula oleh kondisi atau status sosial ekonomi keluarga.

\section{Pendidikan}

Pendidikan merupakan media sosialisasi yang terarah bagi anak. Pendidikan akan memberikan warna terhadap kehidupan sosial anak di masa yang akan datang.

\section{Kapasitas Mental : Emosi dan Intelegensi}

Kapasitas emosi dan kemampuan berpikir mempengaruhi banyak hal, seperti kemampuan belajar, memecahkan masalah, berbahasa, dan menyesuaikan diri terhadap kehidupan di masyarakat.

\section{Pengaruh Perkembangan Sosial terhadap Tingkah Laku}

Dalam perkembangan sosial, para remaja dapat memikirkan perihal dirinya dan orang lain. Pemikiran itu terwujud dalam refleksi diri, yang sering mengarah pada penilaian diri dan kritik dari hasil pergaulannya dengan orang lain.

\section{Mengembangkan Keterampilan Sosial pada Remaja}

Sebagai makhluk sosial, remaja dituntut untuk mampu mengatasi segala permasalahan yang timbul sebagai hasil dari interaksi dengan lingkungan sosial dan mampu menampilkan diri sesuai dengan aturan atau norma yang berlaku.

Keterampilan sosial dan kemampuan penyesuaian diri menjadi semakin penting dan krusial manakala anak sudah menginjak masa remaja. Hal ini disebabkan pada masa remaja, ia sudah memasuki dunia pergaulan yang masih luas yang pengaruh teman-teman dan lingkungan sosial akan sangat menentukan.

Berdasarkan kondisi tersebut amatlah penting bagi remaja untuk mengembangkan keterampilan-keterampilan sosial dan kemampuan untuk menyesuaikan diri. 
Dalam kehidupan remaja terdapat delapan aspek yang menuntut keterampilan sosial (social skills), yaitu :
a. Keluarga
b. Lingkungan
c. Kepribadian
d. Rekreasi
e. Pergaulan dengan lawan jenis
f. Pendidikan
g. Persahabatan dan solidaritas kelompok
h. Lapangan kerja

\section{Implikasi Pengembangan Hubungan Sosial Remaja terhadap penyelenggaraan pendidikan}

Masa remajamerupakan masa mencari jati diri sehingga ia memiliki sikap yang terlalu tinggi dalam menilai dirinya atau sebaliknya. Pola kehidupan remaja yang berbeda dengan kelompok dewasa dan kelompok anak-anak dapat menimbulkan konflik sosial. Di sekolah perlu sering diadakan kegiatan bakti sosial, kelompok belajar, dan kegiatan-kegiatan lainnya di bawah asuhan guru pembimbing.

\section{SIMPULAN DAN SARAN}

\section{A. Simpulan}

Di tinjau dari segi pendidikan, potensi setiap peserta didik harus dipupuk dan dikembangkan. Peserta didik akan merasa aman secara psikologis apabila pendidik dapat menerima peserta didik dalam kondisi apapun. Pendidik mengusahakan suasana dimana peserta didik tidak bisa dinilai oleh orang lain, dan tugas pendidik ialah memberikan pengertian kepada para peserta didik yang membutuhkannya. Dalam penyelenggaraan pendidikan perlu diperhatikan sarana dan prasarana. Disamping itu perkembangan emosi peserta didik sangat erat kaitannya dengan faktor-faktor tertentu. Sekolah merupakan titik tolak dasar untuk pengembangan hubungan sosial peserta didik, para peserta didik juga harus bisa saling menghargai antara yang satu dengan lainnya dan sekolah sebaiknya memberikan pola pengajaran yang demokratis kepada para peserta didik. Kita sebagai individu yang sedang tumbuh dan berkembang, maka dari itu proses pertumbuhan dan perkembangan peserta didik sangat di pengaruhi oleh adanya interaksi antara dua faktor yang sama-sama berperan penting.

\section{B. Saran}

Diharapkan pendidikan bagi peserta didik dapat tumbuh dan berkembang sesuai dengan yang kita inginkan.

\section{DAFTAR PUSTAKA}

Arikunto, 2012. Dasar-Dasar Evaluasi Pendidikan. Jakarta : Media Persada

Aunurrahman. 2012. Belajar dan Pembelajaran. Bandung : Alfabeta

Bahri Djamarah, Syaiful dan Aswan Zain. 2013. Strategi Belajar Mengajar. Jakarta : Rineka Cipta 
Samio, S.Pd, M.Pd : Aspek - Aspek Pertumbuhan dan Perkembangan Peserta Didik

file:///D:/Gangguan\%20Pada\%20Sistem\%20Koordinasi\%.html (diakses pada 17 Februari 2016)

Harjanto. 2008. Perencanaan Pengajaran. Jakarta : Rineka Cipta

https://iceteazegeg.wordpress.com/2010/09/10/strategi-pembelajaranekspositori// (diakses pada 17 Februari 2016)

http://rizalsuhardieksakta.blogspot.com/2012/07/struktur-neuron.html (diakses pada 17 Februari 2016)

http://suryapuspita.wordpress.com/2012/04/21/keunggulan-dan-kelemahan-strategiekspositori/) (diakses pada 17 Februari 2016)

http://www.info-kes.com/2012/10/struktur-otak-dan-fungsinya.html (diakses pada 17 Februari 2016).

Hurlock, E.B.1993.Psikologi Perkembangan.Jakarta: Erlangga

Husdarta, JS dan Yudha Saputra. 2013. Belajar dan Pembelajaran. Bandung : Alfabeta

Husdarta. Kusmaedi, Nurlan.2010.Pertumbuhan dan Perkembangan Peserta Didik.Bandung: Alfabeta

Karmana, Oman. 2008. Cerdas Belajar Biologi Untuk Kelas XI SMA Program IPA. Bandung : Grafindo Media Pratama

Priadi, Arif. 2009. Biologi Untuk SMA Kelas XI. Jakarta : Yudistira

Sagala, Syaiful. 2009. Konsep dan Makna Pembelajaran. Bandung : Alfabeta

Sanjaya, Wina. 2009. Strategi Pembelajaran Berorientasi Standar Proses Pendidikan. Jakarta : Kencana Prenada Media Group

Sudjana, 2005. Metode Statistika Edisi 6. Bandung : PT Tarsito 